\title{
Journalists and Public Relations professionals: from influence and dependence to journalistic disintermediations
}

\author{
Leire Iturregui-Mardaras; Juan-José Gutiérrez-Cuesta; María-José Cantalapiedra- \\ González
}

Nota: Este artículo se puede leer en español en:

http://www.elprofesionaldelainformacion.com/contenidos/2020/may/iturregui-gutierrez-cantalapiedra_es.pdf

How to cite this article:

Iturregui-Mardaras, Leire; Gutiérrez-Cuesta, Juan-José; Cantalapiedra-González, María-José (2020). "Journalists and Public Relations professionals: from influence and dependence to journalistic disintermediation". El profesional de la información, v. 29, n. 3, e290320.

https://doi.org/10.3145/epi.2020.may.20

Manuscript received on 11 November 2019 Accepted on 13 April 2020

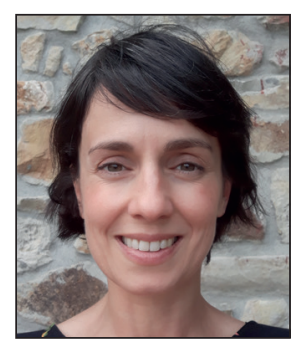

Leire Iturregui-Mardaras $\square$ https://orcid.org/0000-0001-9675-4218

Universidad del País Vasco

Facultad de Ciencias Sociales y de la Comunicación

Campus de Bizkaia, Barrio Sarriena, s/n. 48940 Leioa, Spain

leire.iturregui@ehu.eus

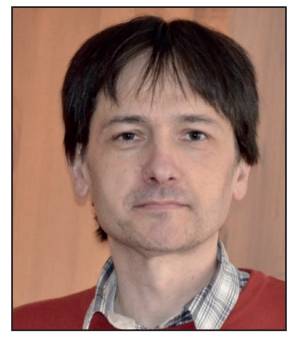

Juan-José Gutiérrez-Cuesta

https://orcid.org/0000-0002-3288-4993

Universidad del País Vasco

Facultad de Ciencias Sociales y de la Comunicación

Campus de Bizkaia, Barrio Sarriena, s/n.

48940 Leioa, Spain

juanjose.gutierrez@ehu.eus

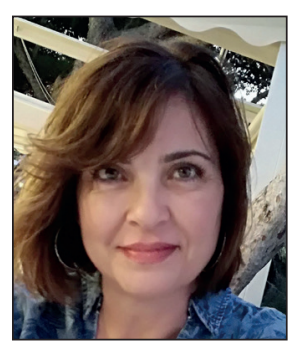

María-José Cantalapiedra-González

https://orcid.org/0000-0003-4961-2326

Universidad del País Vasco

Facultad de Ciencias Sociales y de la

Comunicación

Campus de Bizkaia, Barrio Sarriena, s/n.

48940 Leioa, Spain

mariajose.cantalapiedra@ehu.es

\section{Abstract}

Relations between journalists and Public Relations professionals have been the subject of various investigations. In a context in which great precariousness in the media coincides with an increase and professionalization of communication agencies, we propose to study their informational relations. Our objective is to determine the perceptions of journalists and Public Relations professionals regarding their work and profession, identify how the influences between these two groups of professionals are established, and evaluate their routines and interactions. This research has been carried out using the qualitative discussion group technique $(n=43)$. Among the results, the media's weakness stands out in the face of Public Relations that is experiencing a golden age, capable of exercising not only a relationship of influence that fits with the "determination model" but also aspiring to journalistic disintermediation.

\section{Financing}

This article is part of the scientific production of the Consolidated Research Group IT1081-16 and the research project CSO2014-56196-R. The authors are grateful to the University of Basque Country for funding the research stay at the Department of Communication Studies and Media Research (IfKW) at LMU Munich.

Acknowledgements

Thanks are given to the PRs and journalists who were interviewed for their accessibility and contribution towards this work. And to Pepe Cervera. 


\section{Keywords}

Public Relations; Journalism; Communication agencies; Communication offices; Source journalism; Corporate communication; Organizational communication; Media relations; Agenda setting; Precariousness of journalism; Mediatization; Journalistic disintermediation; Professionals; Journalists; Public Relations practitioners.

\section{Introduction}

This work contributes to the study of the relations between journalists and Public Relations professionals. Media relations or information relations with the media have represented one of the main functions of those responsible for communication agencies (Almansa-Martínez, 2009), and the latest research confirms that the work of Public Relations departments "is preferably oriented" towards media relations in $86.21 \%$ of cases (Túñez-López; Costa-Sánchez; Míguez González, 2018, pp. 936; 928).

Historically, the study of this relationship has been approached in terms of mistrust (Aronoff, 1975). It is common among journalists to refer to agencies as "the dark side," even for lecturers in the educational stage at university (White; Shaw, 2005), which may condition professionals from the beginning of their journalistic career (Sallot; Johnson, 2006, p. 158). In that study, the majority of journalists (55\%) rated their relationship with agencies as positive or very positive, but $18 \%$ described it in terms of "love/hate or a necessary evil" (2006, p. 154), and the authors noted an increase in this sentiment. In Spain, researchers in this field affirm that

"these love/hate relationships [...] seem to be perpetuating themselves" (Fernández-Souto; Almansa-Martínez; Castillo-Esparcia, 2018, p. 8).

In this context, personal relationships become one of the keys for a better understanding (Waters; Tindall; Morton, 2010, p. 245; Lewis; Williams; Franklin, 2008, p. 2). It has been reported that 33\% of journalists despise Public Relations activity from a general perspective, but show more positive attitudes towards individual professionals with whom they work closely, in what has been dubbed the "Jeffers syndrome" (Sallot; Johnson, 2006, p. 154).

In the 1970s, Herbert Gans used the idiom "It takes two to tango" (Gans, 1979, p. 116) to describe and synthesize the cooperation or collaboration between both parties (Lewis; Williams; Franklin, 2008, p. 1), although he qualified that such initiatives stemmed, to a greater extent, from Public Relations. This is known as media pitching, or the work of the agencies to "suggest" issues to journalists via different channels, to establish themselves not only as news sources but as actors in the agenda-setting process (Zoch; Molleda, 2006).

Indeed, the literature on informative media relations is painted against the backdrop of influence. Understood as a concept with different meanings (Obermaier; Koch; Riesmeyer, 2015), this has been the basis on which various theoretical models have been built to study media relations (Baerns, 1979; Bentele; Liebert; Seeling, 1997; Waters; Tindall; Morton, 2010; Lee; Yip; Chan, 2018). In applied research, this influence has mainly been studied using quantitative techniques (Macnamara, 2014), analyzing the amount of information published by the media that originates from agencies. The results yield figures from 25\% to 80\% (Sallot; Johnson, 2006; Macnamara, 2014; Obermaier; Koch; Riesmeyer, 2015). In Spain as well, several studies have been carried out on this basis since the creation of the first communication agencies, yielding percentages that range between 50\% and 75\% (Ramírez-de-la-Piscina, 1995; Castillo-Esparcia, 2004).

Among the possible causes, the pressure on journalists and the lack of resources in newsrooms have been highlighted, which generate greater dependence on "information subsidies" (Gandy, 1982) from agencies, to the detriment of journalistic quality and independence (Lewis; Williams; Franklin, 2008, p. 1). In Spain, precariousness can be considered to be an endemic disease of the journalistic profession, and many voices, from both the academic and professional spheres, have denounced the conditions in which such professionals carry out their work (Cantalapiedra, 1997; Cantalapiedra; Coca; Bezunartea, 2000; Caro-González; Jiménez-Marín, 2006; López-Hidalgo; Mellado-Ruiz, 2006; Ufarte-Ruiz, 2007; Salaverría; García-Avilés, 2008; Suárez-Villegas; Romero-Domínguez; Almansa-Martínez, 2009; Figueras-Maz et al., 2012; Gómez-Mompart; Gutiérrez-Lozano; Palau-Sampio, 2015; Cantalapiedra-González; Gutiérrez-Cuesta, 2019).

Meanwhile, the number of professionals working in agencies is continuously increasing (Carrillo-Durán, 2016; APM, 2004; 2016). In the latest reports from the Madrid Press Association, its president, Victoria Prego, declared that

"there are few medium or even small companies that have not assumed that good communication is essential" (APM, 2016, p. 9).

and that what

"was for many years a practice typical of large companies, is now almost a universal phenomenon" (APM, 2017, p. 7).

In this context, this work proposes a qualitative study of the relationships between journalists and Public Relations managers:

RQ1: To determine the perceptions of journalists and agencies with respect to their work and profession.

RQ2: To identify how these relationships of influence are established and materialized.

RQ3: Provide an approximation to the routines and interactions of these two groups of professionals. 
This research was carried out during the first half of 2018 using a qualitative methodology based on three discussion groups made up of journalists of different professional categories from different media and supporting activities, as well as professionals of different professional categories from the communications field, both institutional and commercial or associations $(n=43)$.

\section{Theoretical framework}

\subsection{From determination theory to intereffication model: a round trip?}

Barbara Baerns proposed the "determination model" in 1979. She assumed that much of journalistic activity relies on Public Relations, which determines either the issues covered by (agenda building/issue generating) or the timing of the media. She chose the term "determination" to define this influence (Baerns, 1979), considering it to be a one-way influence, from agencies to journalists.

Almost two decades later, Bentele, Liebert, and Seeling (1997) proposed the "intereffication model" describing a bidirectionality influence between agencies and journalists (Bentele; Nothhaft, 2008, p. 35). They incorporated the psychosocial dimension with the objective and temporal ones, linked to the personal and social relationships between both parties. They recognize the ability of agencies to determine the topics and timing for journalists, but clarify that important media professionals have the ability to resist this scheme.

Since the formulation of these two theories, the context in which journalists and Public Relations personnel carry out their work and interact has changed, and new frameworks that are also based on influence have been proposed. Some authors have proposed an inversion of the traditional process and suggested that the media are no longer passive in the face of the action of Public Relations professionals:

"Media relations is becoming more relationship-focused and centered on a continued dialogue rather than a series of one-sided media pitches" (Waters; Tindall; Morton, 2010, p. 261).

Faced with this recognized effect by which Public Relations professionals propose topics to the media via different channels, known as media pitching, they consider that there are journalists who actively request information from Public Relations to create news, in an activity known as media catching (Waters; Tindall; Morton, 2010, pp. 242-243).

Linked to this, the press engagement behavior model starts from the perspective of "co-creation" (Botan; Taylor, 2004) and proposes that Public Relations participates actively in the creation of information together with journalists. They add that this implies four dimensions:

"Information seeking, information sharing, responsible behavior and personal interaction" (Lee; Yip; Chan, 2018, p. 493).

However, when faced with these proposals, it is worth questioning the extent to which, in a context in which job insecurity in the journalistic profession is reaching historical levels while the number of professionals in communication agencies is increasing more than ever, we are not witnessing a model that is closer to the passive (O'Neill; O'Connor, 2008, p. 489) or desk-bound journalist (Lewis; Williams; Frankin, 2008, p. 1), which assumes the inability of journalists to resist. Ultimately, we ask ourselves whether we are not returning to a determination model.

\subsection{Influence as the backbone of a complex relationship: conditioning factors}

The ability of Public Relations to set the agenda has mostly been studied using quantitative techniques, to identify the percentage of published information that originates from agencies. Jim Macnamara, in a review of work from the last century, concluded that

" $40-75 \%$ of the content of allegedly independent media is routinely sourced from or influenced by PR" (Macnamara, 2014, p. 741),

and some works affirm that this percentage varies from 25\% to 80\% (Obermaier; Koch; Riesmeyer, 2015).

Among the causes that explain these figures, the professional and working conditions of journalists stand out. Thomasena Shaw and Candace White conclude that the dependence of journalists on material generated by Public Relations is mainly

"due to 'inadequate staffing levels in most newspapers'" (Shaw; White, 2004, p. 499).

Lewis, Williams, and Franklin (2008) established a clear cause-effect relationship between working conditions and dependence on Public Relations. Along this line, O'Neill and O'Connor highlight the importance of resources for the exercise of independent and investigative journalism, as they prevent the relationship between source and journalist from interfering with the responsibility of the media to act in favor of the public interest (O'Neill; O'Connor, 2008, p. 488).

However, as revealed by the latest data published in the Worlds of journalism study led by Thomas Hanitzsch, $40.4 \%$ of Spanish journalists consider that the influence of Public Relations on journalism has increased somewhat or greatly in recent years, while $86.2 \%$ affirm that the time they can dedicate to investigation has decreased a lot or quite a lot (Worlds of journalism study, 2017). 
At the same time, in Spain, the creation and consolidation of Public Relations occurred later than in other European countries (Ramírez-de-la-Piscina, 1995; Cárdenas-Rica, 1999; Almansa-Martínez, 2004; García-Orosa, 2005; Xifra; Lalueza, 2009; Túñez-López, 2012), although in the last decade, the number of professionals dedicated to Public Relations has increased considerably, resulting in a transfer of journalists from media to agencies (APM, 2017).

Certainly, this increase in the number of professionals working in Public Relations has coincided with a worsening of the professional and working conditions of Spanish journalists. Doubtless, the combination of these factors has implications for the relations of influence established between both groups of professionals.

\subsection{The precariousness of journalism: an endemic disease in Spain}

In Spain in particular, precariousness constitutes an endemic evil of the journalistic profession. Caro-González and Jiménez-Martín (2006, p. 323) describe a working environment in which working conditions are "quite precarious," with "low" wages and "quite high" instability. Previously, Iglesias-Real affirmed that

"the violation of working conditions is currently the most widespread method of brain washing and dilution of original thought for journalists and thereby the whole of society" (Iglesias-Real, 2002, p. 506).

Ufarte-Ruiz adds that

"the context in which it operates is deteriorating both labor relations and the professional rights of journalists" (Ufarte-Ruiz, 2007, p. 409).

In a study covering Catalonia, the Basque Country, Madrid, and Andalusia, Figueras-Maz et al. (2012) found that job uncertainty and insecurity were the issues of greatest concern to such professionals. Meanwhile, Suárez-Villegas, Romero-Domínguez and Almansa-Martínez expressed this in the same terms when they describe

"the terrible working conditions of the professionals" (2009, p. 169).

Salaverría and García-Avilés warn of an increase in precariousness, of cuts in the workforce, and of

"very low wages, which in many cases do not even reach those of an unskilled worker" (Salaverría; García-Avilés, 2008, p. 45).

Gómez Mompart, Gutiérrez-Lozano, and Palau-Sampio point out that Spanish journalists are aware that

"job insecurity poses an evident threat to quality” (Gómez-Mompart; Gutiérrez-Lozano; Palau-Sampio 2015, p. 150), coinciding with previous studies in which Cantalapiedra-González denounced that journalists in the local sector worked

"in poor working conditions and with little appreciation of their efforts" (Cantalapiedra-González, 1997).

and that, among Basque journalists, the

"main concerns are related to the quality of work, although they consider that the greatest problem facing the profession is job insecurity" (Cantalapiedra-González; Coca; Bezunartea, 2000, p. 1).

The same discourse can be heard from professional and union associations. The Federation of Spanish Journalists' Associations (FAPE) warns of a decline in press freedom due to, among other things, precariousness. Likewise, the Federation of Journalists' Unions (FeSP) regrets

"the apparently unrestrained degradation of the working and professional conditions of journalists".

\subsection{The journalistic crisis versus the increase of agencies: from influence to convergence?}

In this context, Dinan and Miller affirm that the "scale and scope" of the Public Relations industry is such that the ideal model of investigative journalism, the publication of true exclusives, or the institutional role of the press as the fourth estate are all becoming increasingly unsustainable (Dinan; Miller, 2009, p. 252).

Esser and Strömbäck (2014, p. 6) identified four dimensions of the mediatization of policies:

- the degree to which the media constitute the main source of information on politics and society;

- their independence from other political and social institutions;

- the extent to which the media guide content and coverage on politics and current affairs;

- whether institutions are guided by a media-based logic.

In the current context, some doubts arise regarding whether agencies are the main source of information, the independence of the media with respect to the institutions regarding their ability to guide the content and coverage of politics and current affairs, and even whether media-based logic intervenes in the activity of institutions, organizations, and political actors. 
In 2008, Deuze proposed that

"the boundaries between journalism and other forms of public communication [...] are vanishing" (Deuze, 2008, p. 4).

One year later, Dinan and Miller writed that

"the integration of the PR and media industries is in its early stages" (Dinan; Miller, 2009, p. 252),

while some research has observed that

"the lines between journalism and PR are becoming increasingly blurred" (Mellado-Ruiz; Hanusch, 2011, p. 384), even though convergence is occurring between journalism and Public Relations (Macnamanra, 2014; Verčic; Verčic; Sriramesh, 2015).

\section{Methodology}

The issues investigated herein, posed as they are in the context of the relations of influence between journalists and communication agencies, require a qualitative approach. The theoretical-methodological approach used in the present study is phenomenological, since it focuses on the subjective individual experiences of the participants to determine their perceptions and the meaning of a phenomenon or experience (Hernández-Sampieri; Fernández-Collado; Baptista-Lucio, 2006). The discussion group approach was chosen because, as expressed by Ibáñez (1979), it is a concrete technology, unlike survey methods, which represent an abstract technology; That is, the research team intervenes in the process, resulting in a dialectical process.

An intentional rather than statistical sample was selected using two databases previously prepared within the framework of the research project: one of journalists and the other of those responsible for communication at institutional, commercial, and association levels. Among these, a first filter was applied based on criteria for the homogeneity and heterogeneity of the groups, while the second was applied, notwithstanding the interest and attitude of the participating subjects, based on their availability resulting from their agendas. The contacts were made by the members of the research team of this project.

Three discussion groups were held in Madrid, in a room provided by Universidad Rey Juan Carlos, during the first half of 2018. Regarding the composition of the groups, the aim was to promote discussion among the two groups of participants, not in isolation but between each other, so the three groups were designed to represent the diversity of

- professional journalistic practice, viz. in terms of media, supporting activity, and job category, and of

- professional communication practice in different organizations (commercial, institutional, and association) and professional category. Likewise, it was borne in mind that

"groups of more than ten people are more difficult to coordinate and their participants find their possibilities for expressing and sharing their opinions and visions on the subject to be greatly reduced" (Llopis-Goig, 2004, p. 100).

However, taking into account "the relationship between the topic of discussion and the profile of the participants" as well as the interest "in discovering a wide range of opinions," the research team made the methodological decision to form large groups. Table 1 presents the characteristics of the participants in each group, using a scheme similar to that proposed by Lee, Yip, and Chan (2018, p. 495).

The topics discussed were the objects of this research, viz. their perceptions of their work, professional and personal relationships, routines, and communication tools. Each session was videotaped to identify each speaker in the subsequent transcription for analysis of the content in each category.

\section{Results and discussion}

\subsection{Public Relations agencies, journalists, and vice versa: Perceptions, relationships of (mis)trust, and the psychosocial dimension}

4.1.1. There is two-way mistrust between both groups of professionals: From the journalistic field, communication agencies are accused of being "the dark side," while the latter also criticize that there is "darkness" in the media

The media have traditionally mistrusted the work of the agencies, and this skepticism regarding the focus of the information they provide remains latent among journalists. However, communication departments also point out the lack of professionalism among journalists.

At the beginning of the discussion groups, there were hopes for the "tango," appealing to a "relationship based on necessary cooperation" albeit recognizing the

"different objectives that cause a certain tension," hence the famous nickname of the "dark side" (journalist, freelance, G1.3).

Skepticism and self-defense, especially among experienced journalists, reveal this mistrust from the journalistic profession:

"It is called the dark side because they are a marketing tool. They will never say anything that goes against their interests, and that's where journalists come in" (journalist, state media, G1.9). 
Table 1. List and characteristics of participants in the discussion groups

\begin{tabular}{|c|c|c|c|c|c|}
\hline Code & Sector & $\begin{array}{l}\text { Type of } \\
\text { entity }\end{array}$ & Category & Years of experience & Gender \\
\hline G1.1 & Communication media & Private & Head of innovation & 20 as journalist & Male \\
\hline $\mathrm{G} 1.2$ & Third (social) sector & Private & Communications manager & 15 in PR & Male \\
\hline $\mathrm{G} 1.3$ & Journalism & Private & Freelance & 20 as journalist & Male \\
\hline G1.4 & Communication media & Private & Director & 16 as journalist, 14 in PR & Male \\
\hline G1.5 & Communication media & Private & Digital and network manager & 10 as journalist, 3 in PR & Female \\
\hline G1.6 & Third (social) sector & Private & Communication manager & 8 in PR & Male \\
\hline G1.7 & Communication agency & Private & Director & 14 as journalist, 8 in PR & Female \\
\hline $\mathrm{G} 1.8$ & Journalism & Public & Director & 25 as journalist, 1 in PR & Male \\
\hline G1.9 & Journalism & Private & Journalist & 30 as journalist & Male \\
\hline G1.10 & Institutional & Public & Communications manager & 6 as journalist, 3 in PR & Male \\
\hline G1.11 & Institutional & Public & Communications manager & 12 as journalist, 4 in PR & Male \\
\hline G1.12 & Companies & Private & Internet manager & 8 as journalist, 10 in PR & Male \\
\hline G1.13 & Journalism & Private & Freelance & 20 as journalist & Male \\
\hline G1.14 & Companies & Private & Communications director & 10 in PR & Female \\
\hline G1.15 & Companies & Private & Online communications manager & 11 in PR, 5 in journalism & Male \\
\hline Code & Sector & $\begin{array}{l}\text { Type of } \\
\text { entity }\end{array}$ & Category & Years of experience & Gender \\
\hline $\mathrm{G} 2.1$ & Culture & Private & Communications manager & 8 in PR & Female \\
\hline $\mathrm{G} 2.2$ & Journalism & Private & Journalist & 10 in PR, 5 as journalist & Male \\
\hline $\mathrm{G} 2.3$ & Journalism & Private & Journalist & 10 as journalist & Male \\
\hline $\mathrm{G} 2.4$ & Manufacturing & Public & Communications manager & 20 as journalist, 10 in PR & Male \\
\hline $\mathrm{G} 2.5$ & Third (social) sector & Social & Communications manager & 25 in PR & Male \\
\hline G2.6 & Economics & Public & Communications manager & 18 in PR & Female \\
\hline G2.7 & Journalism & Private & Freelance & 20 as journalist & Male \\
\hline $\mathrm{G} 2.8$ & Journalism & Private & Journalist & 30 in journalism, 1 in PR & Male \\
\hline G2.9 & Sports & Private & Press officer & 8 as journalist. 18 in PR & Male \\
\hline $\mathrm{G} 2.10$ & Journalism & Public & Information network manager & 30 as journalist, 4 in PR & Male \\
\hline G2.11 & Institutional & Public & PR manager & 14 as journalist, 8 in PR & Male \\
\hline $\mathrm{G} 2.12$ & Transport & Public & Communications manager & 25 in PR & Female \\
\hline $\mathrm{G} 2.13$ & Transport & Public & Marketing and communications & 24 in PR & Female \\
\hline Code & Sector & $\begin{array}{l}\text { Type of } \\
\text { entity }\end{array}$ & Category & Years of experience & Gender \\
\hline G3.1 & Banking & Private & Communications manager & 14 as journalist, 12 in PR & Male \\
\hline $\mathrm{G} 3.2$ & Banking & Private & Communications manager & 20 as journalist, 15 in PR & Male \\
\hline G3.3 & Journalism & Private & Content manager & 25 in journalism & Female \\
\hline G3.4 & Economics & Public & Communications director & 30 in PR & Male \\
\hline G3.5 & Culture & Association & Head of agency & 8 in PR & Female \\
\hline G3.6 & Agencies & Private & Director & 15 in PR & Female \\
\hline G3.7 & Culture & Public & Head of agency & 24 in PR & Male \\
\hline G3.8 & Economics & Cooperative & Communications director & 5 in PR & Male \\
\hline G3.9 & Innovation & Private & Marketing department & 12 in PR & Female \\
\hline G3.10 & University & Public & Communications agency & 15 in PR & Female \\
\hline G3.11 & Economics & Private & Communications manager & 22 in PR & Male \\
\hline G3.12 & Journalism & Public & Journalist & 8 in journalism & Female \\
\hline G3.13 & Companies & Private & Internet manager & 8 as journalist, 10 in PR & Male \\
\hline G3.14 & Journalism & Private & Freelance & 24 in journalism & Male \\
\hline G3.15 & Journalism & Private & Manager & 40 in journalism & Male \\
\hline
\end{tabular}


The role of the agencies as advertisers and the pressure exerted by the threat of withdrawing advertising campaigns in the case of publishing unfavorable information is another of the criticisms made by journalism professionals (G1.1).
Nostalgia is prevalent in the discourse of the most experienced journalists, regarding what the profession was and should be, but is no longer

However, this mistrust is not one-way. Those working in the agencies clarify that

"it seems that there is only one dark side while there is no darkness in the light side, but there is" (head of communication, public institution, G1.11).

This accusation refers to the editorial position of the media, who nevertheless avoid self-criticism and highlight the crisis as the central cause. They regret the loss of prestige of the profession, and pessimism weighs down their contributions, with catastrophic-sounding opinions:

"Trust and respect have been broken. We do not respect the sources. Sources do not respect us, advertisers do not respect the media, and we do not respect citizens. Journalism and even communication are increasingly devalued and discredited" (G1.4).

Nostalgia is prevalent in the discourse of the most experienced journalists, regarding what the profession was and should be, but is no longer, and referring to

"journalism as understood by those of us who have a certain age and a spirit that previously lived in the newsrooms but that, largely due to the crisis, has now ceased" (journalist, state media, G1.9),

in clear reference to the role of the watchdog granted to the profession in most Western countries (Hanitzsch, 2011).

\subsubsection{Agencies and journalists point to personal relationships and recognition of "the other" as key elements to gua- rantee professionalism}

Journalists and communication managers defend the legitimacy of their own work and question the impartiality of the other, but the psychosocial dimension (Bentele; Liebert; Seeling, 1997) stands out as one of the keys to understanding what both groups of professionals consider to be important, identifying two issues as essential to start the dance:

- On the one hand, personal relationships must be cultivated through direct contact despite the development of new technologies, and the proliferation of different channels for interaction between both groups of professionals.

- On the other hand, the professional career is decisive to the understanding between both groups of professionals, with journalists gaining experience in agencies, and vice versa. And certainly, transfers "from one side to the other" are more the norm than the exception.

The media vindicates its vocation to public service and the journalistic method as guarantors of its professionalism, while questioning the impartiality of the information approach adopted by agencies:

"Communication generates states of opinion that favor the interests of the person who pays. Journalism is a public service that is carried out in accordance with standards" (journalist, state media, G1.4).

The communication departments point to the editorial constraints of the media and question their fairness, and moreover suggest the greater legitimacy in the case of the communication departments of public institutions:

"What's more democratic, that I should be defined by the issues or by the approach of a politician or editor? The politician has been voted for by the people" (G1.11).

To achieve an understanding, it is crucial to recognize the role and expectations of the other. The media are clear regarding what they expect from the agencies: their availability.

"That the sources are available. By whatever means. They are useful to me when I have a question, when I need an expert ... And what makes me very angry? That they don't answer me" (journalist, freelance, G1.13).

The agencies pick up this baton and assure:

"You have to answer everyone, it is fundamental" (G1.7).

However, the lack of trust in "the other" once again generates a crossfire of accusations: journalists criticize Public Relations for distancing them from the news sources, while the agencies criticize the media for trying to "bypass" them to access information directly.

Among the keys to a better understanding, there is a shared recognition of the importance of personal contact, closely linked to the above-mentioned psychosocial dimension. There is a striking difference between younger professionals, who are more reluctant to contact directly, and veterans, who are more inclined towards personal interactions. Among the multiple channels for contact, the telephone is highlighted as a means of establishing trusting relationships, although "control" calls from agencies to journalists are criticized (journalist, state media, G1.9).

These opinions expressed by journalists and agency professionals coincide with the results obtained by Lee, Yip, and Chan, who pointed out that the media demand greater understanding of the operation of newsrooms from agencies, in 
order to provide "relevant and timely information" and build a "win-win relationship" (Lee; Yip; Chan, 2018, p. 498), an understanding that becomes more plausible the greater the knowledge (recognition) of the other. Perhaps for this reason, previous research has already suggested that Public Relations professionals with experience as journalists are more highly valued (Sallot; Johnson, 2006, p. 157), and that the most valued competences among employers are writing and media knowledge (Waters; Tindall; Morton, 2010, p. 242).

\subsection{Influence relationships: determination versus intereffication: Channels, interactions, and professional routines}

4.2.1. The traditional corporate communication tools are the most widely used for media pitching, and in the media there is a debate between weariness and the need for them

Beyond doubt, the aspiration of communication agencies is to influence journalistic routines, from those who confess that their objectives are

"to produce professional information to copy and paste" (head of communication, economic entity, G3.1),

to more measured positions that point to the need to

"resolve doubts, speed up work, offer quick responses, and serve as a 'partner' to the journalist" (agency, third sector, G1.6).

For this, the traditional corporate communication tools continue to be valid, despite the fact that, in recent years, the number of interaction channels between journalists and communication managers has multiplied. The discussion groups agreed with academic research in highlighting email as the main channel (Sallot; Johnson, 2006; Túñez-López; Costa-Sánchez; Míguez-González, 2018), although some journalists confessed that they have opened new personal accounts to screen what "really" interests them, because they are "absolutely bombarded" by email (journalist, state media, G1.9).

In the media, there is a general weariness regarding media pitching:

"I spend my time managing information that comes to me packaged, manufactured, and that they want me to consume" (content manager, regional media, G3.3).

Meanwhile, agencies acknowledge that a

"huge quantity of press releases" are produced, following a model to which both civil servants and "many media" are accustomed (agency, public institution, G1.10).

The press release is the corporate communication tool that is most widely used by agencies (Túñez-López; Costa-Sánchez; Míguez-González, 2018), although some participants in the discussion groups said that they "contribute," but "depending on the sector," while others confessed that they have "practically never" read one .

The press conference, which has traditionally served as a meeting point, is more highly valued by Public Relations professionals than by journalists, who criticize that public officials refuse to answer questions, or that excessive and unjustified press conferences are called, which generate distance between journalists and sources, as criticized by Sallot and Johnson (2006, p. 158). In this context, a divide is beginning to be noted between more veteran Public Relations professionals, who tend towards the press conference format, and journalists, who consider that physical presence is not necessary (Lee; Yip; Chan, 2018, p. 498).

\subsubsection{From media pitching to media catching: an act of rebellion or submission of the journalistic profession?}

Agencies acknowledge that they have no difficulties in accessing the media, and there are even communication managers who say that the opposite phenomenon occurs, viz. that it is journalists who appear in their office asking "what have you got for today?" This would be a clear example of a change of order from the traditional scheme, where agencies went looking for journalists, or a jump from media pitching to media catching. However, this would not be considered as a way to rebel against the abuse of media pitching (Waters; Tindall; Morton, 2010, p. 242), but rather as an absolute dependence on the content generated by Public Relations.

The media acknowledge and regret the decline of the profession and clearly blame the economic crisis. The importance of vocation in journalism emerges in this debate, regardless of working conditions,

"to earn money we would have studied economics" (journalist, public media, G1.8),
The change of basis in the communications model is strongly emphasized by the latent issue observed in many contributions by media professionals: precariousness 
but it is recognized that

"the fundamental value of the journalist lies in his contact list, experience, and the content he generates."

One question directly related to the cuts in the media is that

"newsrooms are opting, for cost reasons, to have very young people, who are very valuable but without sufficient experience to rebel" (journalist, state media, G1.9).

This question is closely related to the ability to resist the influence of Public Relations, as pointed out by Bentele and Nothhaft (2008, p. 35).

This change of basis in the communications model is strongly emphasized by the latent issue observed in many contributions by media professionals: precariousness. They acknowledge that

"the information scenario has never been so good," understanding that there are many "possibilities to search for information in a simple way" (G3.14), but insist that "it is necessary to have people and resources".

The key to the debate, undoubtedly, lies in the resources. And there are journalists who affirm that "there are more agencies than journalists" (G3.4)

\subsection{Journalistic insecurity + professionalization and growth of communication departments: towards a disintermediation of the media?}

The shortage of time and resources in newsrooms and the impact of this situation on the increasing dependence of journalists on material sent by agencies is a reality confirmed by both media and Public Relations professionals. These results coincide with trends described by the Worlds of journalism study (2017) in relation to the shorter time available time and the increased influence of Public Relations agencies, as well as the dependence of the media as indicated by Lewis, Williams, and Franklin (2008) or, more recently, by Fernández-Souto, Almansa-Martínez, and Castillo-Esparcia (2018).

Journalists defend that "real journalism" is being done outside the press conferences, but the agencies consider that "often, journalists settle for the press release". In parallel, they insist on the professionalization of Public Relations, with a person in charge of communication at a bank (G1.15) even stating that, in their department, they do

"brand journalism," defining it as "journalism in order to be transparent, clear, and responsible"

through journalistic genres such as interviews or reports.

This was one of the unexpected turns in the discussion groups, revealing a position and reality that go beyond the aspiration to influence, taking advantage of a context that we could describe as journalistic defenselessness. Communication managers begin to reclaim their "journalistic professionalism" or the journalistic method as a guarantor of the quality of their work in Public Relations. In the case of the communication departments of public institutions, this position was completed by explaining that they do

"public service journalism" (G1.11) and work "practically as if writing for a media outlet" (G1.10). They assume

"journalistic responsibility" in being "obliged to offer communication, local information to citizens" (G1.11).

The final aspiration, therefore, translates into achieving journalistic disintermediation. A veteran journalist explained it this way:

if "agencies usually work through the media" and "journalists are intermediaries," now a "change in the communication system is proposed, which may also have to do with the media crisis and the fact that the media are not providing the intermediation service that was previously obligatory but now optional" (G1.3).

This thus throws at the agencies the accusation that:

"You disintermediate directly. You look for sources by disintermediating the media".

This approach is in agreement with the statements of a journalist interviewed by Jim Macnamara, who warned that Public Relations are

"plugging into people directly now bypassing the traditional routes" (quoted in Macnamara, 2014, p. 746).

However, the distinction is clear among media professionals:

"This is not journalism; it may be technologically similar because information is being disseminated, but journa-

lism has other components" (journalist, state media, G1.9),

referring to the journalistic method that has characterized the profession.

Will the dance go on? 


\section{Conclusions}

Among the main conclusions of this research, the contrast between professionals from the two sides stands out.

- On the one hand, one observes nostalgia and pessimism on the side of journalists, fueled by the precariousness of their profession, the scarcity of resources in the media, and the difficulty of resisting the influence of Public Relations.

- On the other, Public Relations professionals convey that they are living a golden age: they have new tools that open up expectations that were previously impossible to imagine, and the human resources to form large teams of professionals, most of them with a background in the media, aware of the real situation in newsrooms.

Therefore, we are witnessing an absolute imbalance in the dance, with journalists without time or resources facing professionalized agencies that are trying to organize themselves as newsrooms. This sort of upside-down world is especially serious in the context of a politically disaffected society, because one of the questions that arises in this context is whether public opinion observes reality through the prism of communication agencies.

Macnamara considers that one of the consequences of

"disintermediatization" is that it leads to "misinformation and propaganda corrupting the public sphere" (Macnamara, 2014, p. 746),

and points to the role of new technologies in this process. This approach is linked to that proposed by Dinan and Miller, who affirmed that a

"neoliberalization of the public sphere" is taking place (Dinan; Miller, 2009, p. 250).

In this context, ethical dilemmas arise about how to face the elimination of the mediation of the press from the communication process and its implications for public opinion. Among the proposals, the need to reinforce "ethical PR education" can be highlighted (Macnamara, 2014, p. 748), or

"the need to incorporate journalistic criteria into the process of information production in agencies" (Cantalapiedra-González; De-Alzaga-Fraguas; Iturregui-Mardaras, 2018, p. 119).

However, in both cases, this would mean assuming, as predicted by some professionals, the end of high-quality and independent journalism. Recently, Iñaki Gabilondo stated in his investiture speech as honorary doctor of the University of Seville that

"nothing is too expensive when the alternative is to die".

Some lines of interest for future research could be to address the role of new technologies in this area, or the position of managers of media companies in the scenario outlined herein.

\section{References}

Almansa-Martínez, Ana (2004). "Historia de los gabinetes de comunicación en España”. Historia y comunicación social, n. 9, pp. 5-21.

https://revistas.ucm.es/index.php/HICS/article/view/HICS0404110005A

Almansa-Martínez, Ana (2009). "Relaciones Públicas y medios de comunicación. Estudio del caso español". Razón y palabra, n. 70.

https://dialnet.unirioja.es/servlet/articulo?codigo=3103157

APM (2004). Informe anual de la profesión periodística 2004. Madrid: Asociación de la Prensa de Madrid. https://www.apmadrid.es/publicaciones/informe-anual-de-la-profesion

APM (2016). Informe anual de la profesión periodística 2016. Madrid: Asociación de la Prensa de Madrid. https://www.apmadrid.es/publicaciones/informe-anual-de-la-profesion

APM (2017). Informe anual de la profesión periodística 2017. Madrid: Asociación de la Prensa de Madrid. https://www.apmadrid.es/publicaciones/informe-anual-de-la-profesion

Aronoff, Craig (1975). “Credibility of Public Relations for journalists”. Public Relations review, v. 1, n. 2, pp. 45-56. https://doi.org/10.1016/S0363-8111(75)80023-3

Baerns, Barbara (1979). "Öffentlichkeitsarbeit als Determinante journalistischer Informationsleistungen". Publizistik, v. 24, n. 3, pp. 301-316.

Bentele, Günter; Liebert, Tobias; Seeling, Stefen (1997). “Von der determination zur intereffikation. Ein integriertes modell zum verhältnis von Public Relations und Journalismus". In: Bentele, Günter; Haller, Michael. Aktuelle entstehung von öffentlichkeit. Akteure, strukturen, veränderungen, pp. 225-250. ISBN: 9783896692153 
Bentele, Günter; Nothhaft, Howard (2008). "The intereffication model: Theoretical discussions and empirical research". In: Zerfass, Ansgar; Van-Ruler, Betteke; Sriramesh, Krishnamurthy (eds.). Public Relations research, pp. 33-47. Wiesbaden: VS Verlag für Sozialwissenschaften. ISBN: 9783531909189

Botan, Carl H.; Taylor, Maureen (2004). “Public Relations: State of the field”. Journal of communication, v. 54, n. 4, pp. 645-661.

https://doi.org/10.1111/j.1460-2466.2004.tb02649.x

Cantalapiedra-González, María-José (1997). “Periodistas locales”. ZER, v. 2, n. 3.

https://www.ehu.eus/ojs/index.php/Zer/article/view/17325

Cantalapiedra-González, María-José; Coca, César; Bezunartea, Ofa (2000). “La situación profesional y laboral de los periodistas vascos". Zer, v. 5, n. 9.

https://www.ehu.eus/ojs/index.php/Zer/article/view/17441

Cantalapiedra-González, María-José; De-Alzaga-Fraguas, Pedro; Iturregui-Mardaras, Leire (2018). "La convergencia hipermedia en la comunicación corporative". Revista cubana de información y comunicación, v. 6, n. 14, pp. 111-122. http://scielo.s/d.cu/scielo.php?script=sci_arttext\&pid=S2411-99702017000300008

Cantalapiedra-González, María-José; Gutiérrez-Cuesta, Juan-José (2019). “El colaborador y la externalización de las redacciones". En: Ufarte-Ruiz, María-José (coord.). Nuevos perfiles profesionales para el mercado periodístico, pp. 185198. Comunicación Social Ediciones y Publicaciones. ISBN: 9788415544821

Cárdenas-Rica, María-Luisa (1999). "Profesionalización de los gabinetes de prensa municipales". Revista latina de comunicación social, n. 15, pp. 131-141.

Caro-González, Francisco-Javier; Jiménez-Marín, Gloria (2006). “Periodistas: el acceso al mercado laboral”. Ámbitos, n. 15, pp. 313-334.

https://institucional.us.es/revistas/Ambitos/15/Ambitos.2006.i15.17.pdf

Carrillo-Durán, María-Victoria (2016). “Importancia del profesional de la información en la dirección de comunicación de las organizaciones". El profesional de la información, v. 25, n. 2, pp. 272-278.

https://doi.org/10.3145/epi.2016.mar.14

Castillo-Esparcia, Antonio (2004). “Comunicación empresarial e institucional. Estrategias de comunicación”. Zer, v. 9, n. 17, pp. 189-207.

https://www.ehu.eus/ojs/index.php/Zer/article/view/5277

Deuze, Marc (2008). "Understanding journalism as newswork: How it changes, and how it remains the same". Westminster papers in communication and culture, v. 5, n. 2, pp. 4-24.

http://doi.org/10.16997/wpcc.61

Dinan, William; Miller, David (2009). “Journalism, Public Relations and spin”. In: Wahl-Jorgensen, Karin; Hanitzsch, Thomas (eds.). Handbook of journalism studies, pp. 250-264. London: Routledge. ISBN: 9781410618061 https://centreforjournalism.co.uk/sites/default/files/richardpendry/Handbook\%20of\%20Journalism\%20Studies.pdf

Esser, Frank; Strömbäck, Jesper (eds.) (2014). Mediatization of politics: Understanding the transformation of Western democracies. Basingstoke: Palgrave Macmillan. ISBN: 9781137275844

Fernández-Souto, Ana-Belén; Almansa-Martínez, Ana; Castillo-Esparcia, Antonio (2018). “Ética en las relaciones entre los medios de comunicación y los gabinetes de comunicación”. Revista prisma social, n. 22, p. 1-19.

https://revistaprismasocial.es/article/view/2531

Figueras-Maz, Mónica; Mauri-Ríos, Marcel; Alsius-Clavera, Salvador; Salgado-De-Dios, Francesc (2012). "La precariedad te hace dócil. Problemas que afectan a la profesión periodística". El profesional de la información, v. 21, n. 1, pp. 70-75.

https://doi.org/10.3145/epi.2012.ene.09

Gandy, Oscar H. (1982). Beyond agenda setting: Information subsidies and public policy. Norwood, NJ: Ablex. ISBN: 978 0893910969

Gans, Herbert J. (1979). Deciding what's news. New York: Pantheon. ISBN: 9780810122376

García-Orosa, Berta (2005). Los altavoces de la actualidad: radiografía de los gabinetes de comunicación. Netbiblo. ISBN: 8497450973

Gómez-Mompart, Josep-Lluís; Gutiérrez-Lozano, Juan-Francisco; Palau-Sampio, Dolors (2015). “Los periodistas españoles y la pérdida de la calidad de la información: el juicio profesional”. Comunicar, v. 23, n. 45, pp. 143-150.

https://doi.org/10.3916/C45-2015-15 
Hanitzsch, Thomas (2011). "Populist disseminators, detached watchdogs, critical change agents and opportunist facilitators: Professional milieus, the journalistic field and autonomy in 18 countries". International communication gazette, v. 73, n. 6 , pp. $477-494$.

https://doi.org/10.1177/1748048511412279

Hernández-Sampieri, Roberto; Fernández-Collado, Carlos; Baptista-Lucio, Pilar (2006). Metodología de la investigación. MacGraw-Hill. ISBN: 9789701018996

Ibáñez, Jesús (1979). “Cómo se realiza una investigación mediante grupos de discusión”. En: Padua, Jorge. Técnicas de investigación aplicada a las ciencias sociales, pp. 489-501. Fondo de cultura económica. Chile. SA.

Iglesias-Real, María (2002). “Precariedad laboral de los periodistas, la mordaza de la prensa libre. Tentación peligrosa de pasividad”. En: Sierra-Caballero, Francisco; Moreno-Gálvez, Francisco-Javier (eds.). Comunicación y desarrollo en la sociedad global de la información : economía, política y lógicas culturales. Actas del III Encuentro Iberoamericano de Economía Política de la Comunicación, pp. 504-525. Sevilla: Universidad de Sevilla.

https://idus.us.es/handle/11441/61555

Lee, Liane W. Y.; Yip, Leslie S. C.; Chan, Kara (2018). “An exploratory study to conceptualize press engagement behavior with Public Relations practitioners". Public Relations review, v. 44, n. 4, pp. 490-500.

https://doi.org/10.1016/j.pubrev.2018.07.003

Lewis, Justin; Williams, Andrew; Franklin, Bob (2008). “A compromised fourth estate? UK news journalism, Public Relations and news sources". Journalism studies, v. 9, n. 1, pp. 1-20.

https://doi.org/10.1080/14616700701767974

Llopis-Goig, Ramón (2004). Grupos de discusión. Esic Editorial. ISBN: 9788473563734

López-Hidalgo, Antonio; Mellado-Ruiz, Claudia (2006). “Periodistas atrapados en la Red: rutinas de trabajo y situación laboral”. Estudios sobre el mensaje periodístico, v. 12, pp. 161-170.

https://revistas.ucm.es/index.php/ESMP/article/view/ESMP0606110161A

Macnamara, Jim (2014). “Journalism-PR relations revisited: The good news, the bad news, and insights into tomorrow's news". Public Relations review, v. 40, n. 5, pp. 739-750.

https://doi.org/10.1016/j.pubrev.2014.07.002

Mellado-Ruiz, Claudia; Hanusch, Folker (2011). "Comparing professional identities, attitudes, and views in public communication: A study of Chilean journalists and Public Relations practitioners". Public Relations review, v. 37, n. 4, pp. 384-391.

https://doi.org/10.1016/j.pubrev.2011.08.014

O'Neill, Dreirdre; O’Connor, Catherine (2008). "The passive journalist: How sources dominate local news". Journalism practice, v. 2, n. 3, pp. 487-500.

https://doi.org/10.1080/17512780802281248

Obermaier, Magdalena; Koch, Thomas; Riesmeyer, Claudia (2015). “Deep impact? How journalists perceive the influence of Public Relations on their news coverage and which variables determine this impact". Communication research, $v$. 45, n. 7, pp. 1031-1053.

https://doi.org/10.1177/0093650215617505

Ramírez-de-la-Piscina, Txema (1995). "La influencia de los gabinetes de prensa. Las rutinas periodísticas al servicio del poder". Telos, n. 40, pp. 47-57.

Salaverría, Ramón; García-Avilés, José-Alberto (2008). “La convergencia tecnológica en los medios de comunicación: retos para el periodismo". Trípodos, n. 23, pp. 31-47.

https://core.ac.uk/download/pdf/39028971.pdf

Sallot, Lynne M.; Johnson, Elisabeth A. (2006). "Investigating relationships between journalists and Public Relations practitioners: Working together to set, frame and build the public agenda, 1991-2004". Public Relations review, v. 32, n. 2, pp. 151-159.

Shaw, Thomasena; White, Candace (2004). "Public Relations and journalism educators' perceptions of media relations". Public Relations review, v. 30, n. 4, pp. 493-502.

https://doi.org/10.1016/j.pubrev.2004.08.004

Suárez-Villegas, Juan-Carlos; Romero-Domínguez, Lorena R.; Almansa-Martínez, Ana (2009). "El periodismo en el espejo. La profesión analizada por periodistas andaluces". Ámbitos, n. 18, pp. 157-175.

https://dialnet.unirioja.es/servlet/articulo?codigo=3154798

Túñez-López, Miguel (2012). La gestión de la comunicación en las organizaciones. Sevilla y Zamora: Comunicación Social. ISBN: 9788492860937 
Túñez-López, Miguel; Costa-Sánchez, Carmen; Míguez-González, María-Isabel (2018). “Avances y retos de la gestión de la comunicación en el siglo XXI. Procesos, necesidades y carencias en el ámbito institucional". Estudios sobre el mensaje periodístico, v. 24, n. 1, pp. 921-940.

https://doi.org/10.5209/ESMP.59987

Ufarte-Ruiz, María-José (2007). "Las mujeres en el seno de la profesión periodística: de la discriminación a la inserción". Ámbitos, n. 16, pp. 409-421.

https://idus.us.es/handle/11441/68000

Verčic, Dejan; Verčic, Ana-Tkalac; Sriramesh, Krishnamurthy (2015). "Looking for digital in Public Relations". Public Relations review, v. 41, n. 2, pp. 142-152.

https://doi.org/10.1016/j.pubrev.2014.12.002

Waters, Richard D.; Tindall, Natalie T. J.; Morton, Timothy S. (2010). "Media catching and the journalist-Public Relations practitioner relationship: How social media are changing the practice of media relations". Journal of Public Relations research, v. 22, n. 3, pp. 241-264.

https://www.tandfonline.com/doi/abs/10.1080/10627261003799202

White, Candace; Shaw, Thomasena (2005). "Portrayal of Public Relations in mass communication textbooks". Association for Education in Journalism and Mass Communication, San Antonio, Texas.

Worlds of journalism study (2017). Country reports.

https://worldsofjournalism.org/country-reports

Xifra, Jordi; Lalueza, Ferrán (2009). Casos de Relaciones Públicas y comunicación corporativa. Pearson Educación. ISBN: 9788483226117

https://www.auditorlider.com/wp-content/uploads/2019/06/Casos-de-Relaciones-Publicas-y-ComunicacionCorporativa-Jordi-Xifra-y-Ferran-Lalueza.pdf

Zoch, Lynn M.; Molleda, Juan-Carlos (2006). "Building a theoretical model of media relations using framing, information subsidies, and agenda-building”. In: Botan, Carl H.; Hazleton, Vincent (eds.). Public Relations theory II, pp. 279-309. New Jersey: Lawrence Erlbaum Associates. ISBN: 9780203873397

https://doi.org/10.4324/9780203873397

\section{Inforảrea}

\section{Ayudamos a tu organización en la transformación digital y el gobierno de la información}

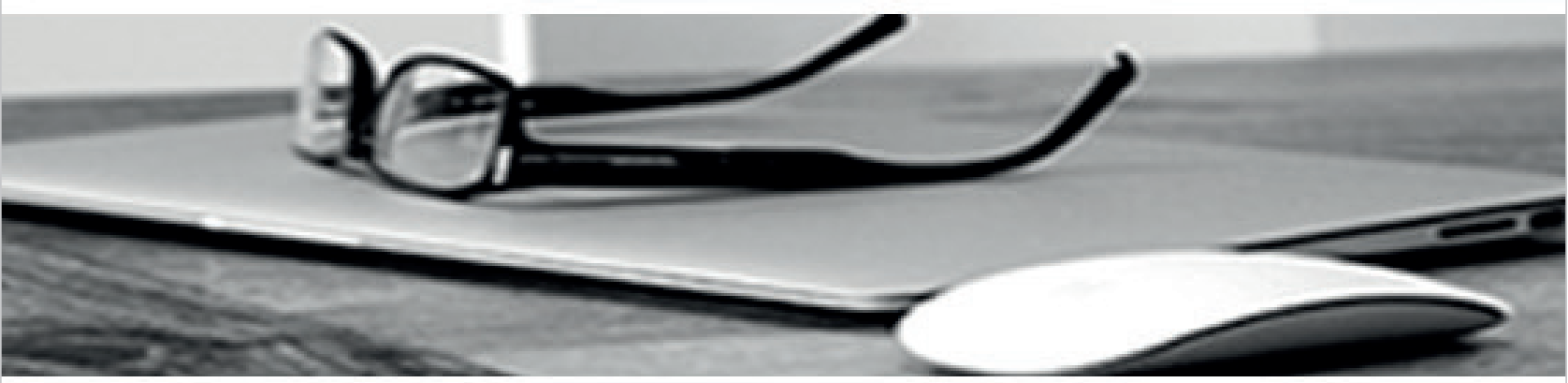

* Consultoría estratégica en gestión y gobierno de la información

* Gestión documental y "records management"

* Gestión de contenidos, intranets corporativas y entornos de colaboración

* Estudios especializados

Clientes satisfechos, cientos de empresas nacionales e internacionales y más de 30 años de experiencia son la mejor garantía de nuestra reputación. 